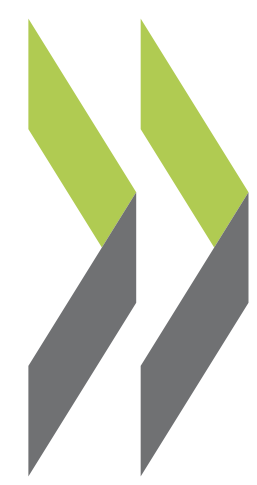

OECD Local Economic and Employment Development (LEED) Papers 2011/07

\title{
Green Jobs Strategy and the Transition to the Low-Carbon Economy in Northern Virginia
}

\section{Peter Garforth,} Dale Medearis 


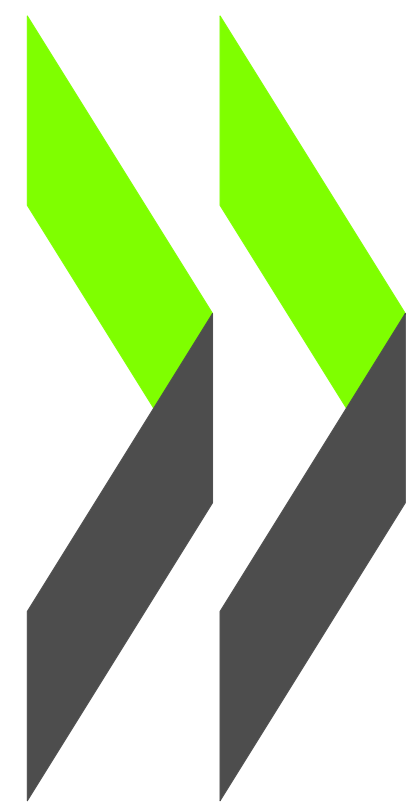

\section{GREEN JOBS STRATEGY AND THE TRANSITION TO THE LOW-CARBON ECONOMY IN NORTHERN VIRGINIA}

APRIL 2011

Peter Garforth and Dale Medearis
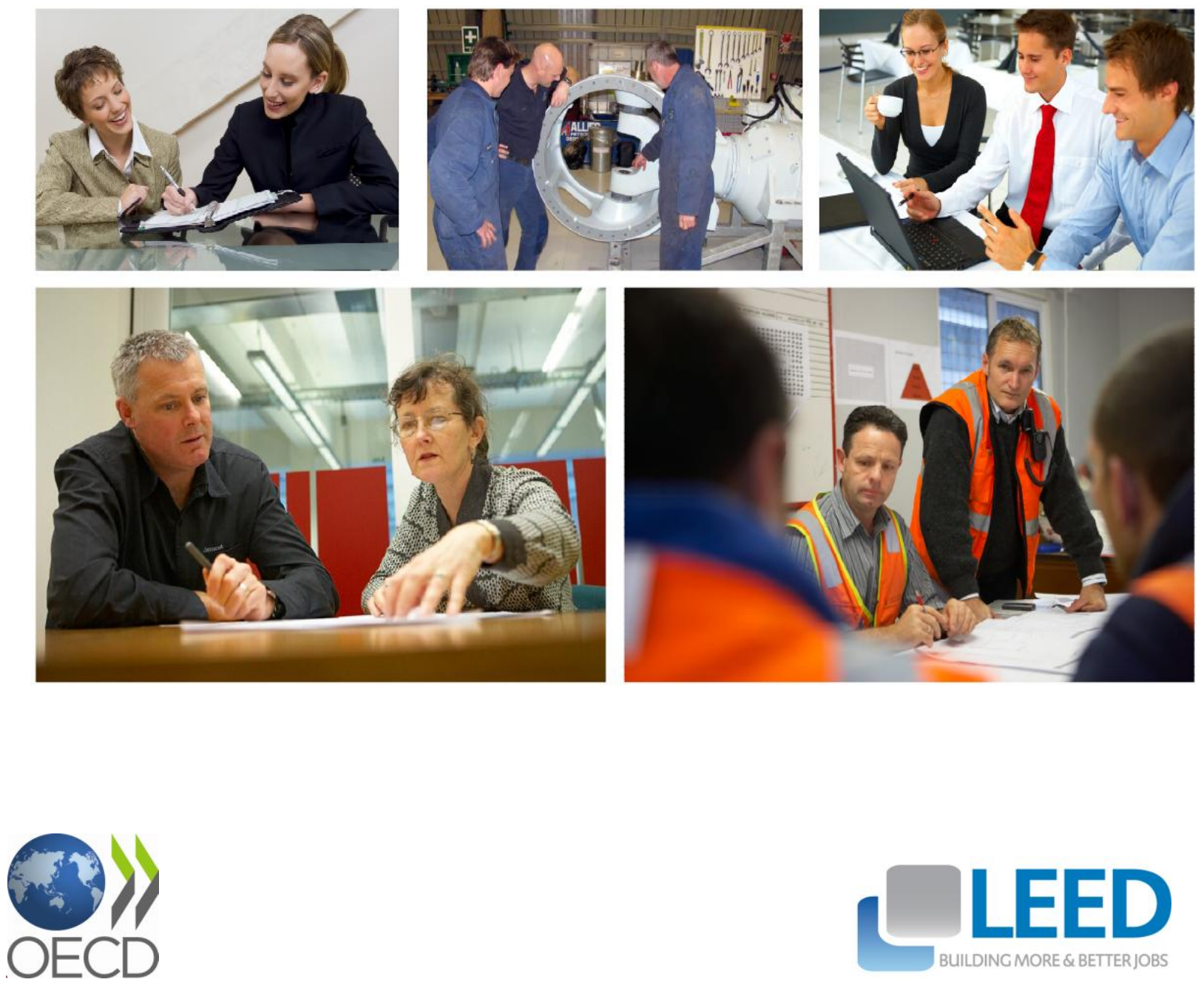


\section{FOREWORD}

This working paper has been prepared by Peter Garforth and Dale Medearis from Northern Virginia Regional Commission \& Garforth International for the Local Economic and Employment Development (LEED) Programme of the Organisation for Economic Co-operation and Development. This paper illustrates how regions are adjusting their strategies to facilitate the transition to a greener economy while stimulating job creation.

This working paper will feed into the wider OECD project on Climate Change, Employment and Local Development being developed by the LEED Programme. The work has been supervised by Gabriela Miranda (OECD Secretariat), who also leads the project.

All errors and omissions are the responsibility of the authors. 


\section{TABLE OF CONTENTS}

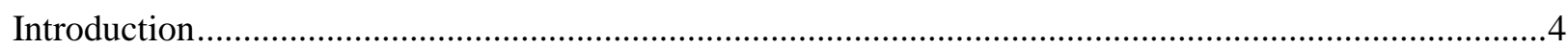

Overview of Regional Energy, Climate and Economic Challenges ....................................................

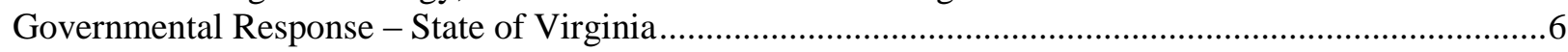

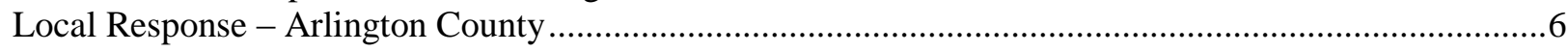

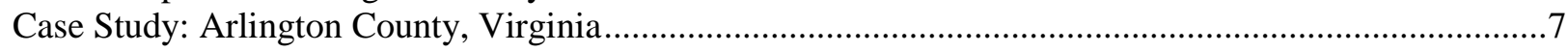

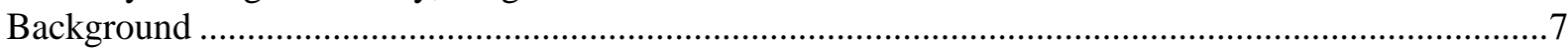

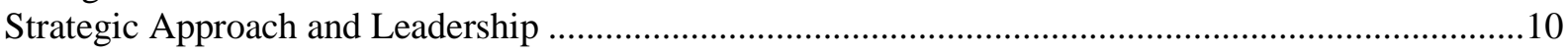

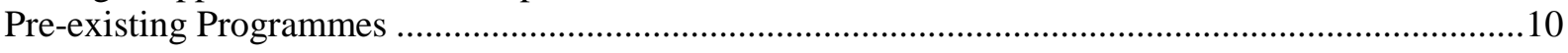

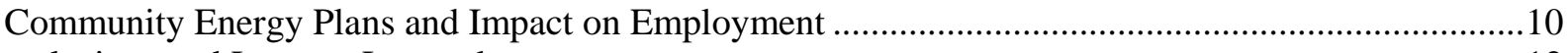

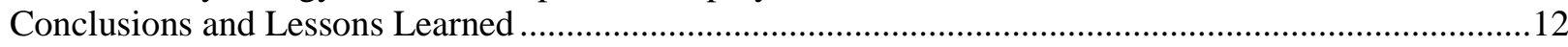

\section{Figures}

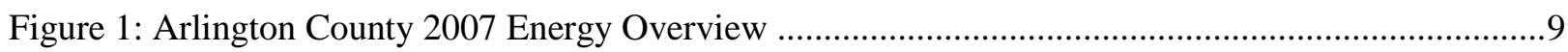

Figure 2: Arlington County - Potential District Energy Zones ............................................................. 


\section{GREEN JOBS STRATEGY AND THE TRANSITION TO THE LOW-CARBON ECONOMY IN NORTHERN VIRGINIA}

\section{Introduction}

The recognition of the vital role of local authorities in economic development, energy efficiency and reducing greenhouse gas emissions is growing rapidly across the US in general and the Northern Virginia region in particular. This recognition has occurred in part because of recent events at the global and national levels, including the lack of a global climate agreement in Copenhagen in 2009, and the absence of clear national-level climate and energy policies in the US. This has placed the burden of greenhouse gas emissions reductions, "green" job creation and energy security squarely on the shoulders of state and local authorities. Many energy-related environmental and economic studies suggest that facing these will become increasingly important for the cities of the Northern Virginia region. Reports such as the Virginia Governor's 2008 Climate Commission suggest that under "business as usual scenarios", energy supply and efficiencies will become less reliable, energy is likely to be more costly, and greenhouse gas emissions will increase. This will cause weather events to be more extreme and amplify negative economic outcomes. ${ }^{1}$

In response, jurisdictions in Northern Virginia are rising to the challenge to develop sustainable energy systems that also contribute to climate change mitigation and job growth in the face of rising energy prices, energy supply uncertainties and rising greenhouse gas emissions. As just one example, Loudoun County, Virginia, developed the nation's first long-term comprehensive "Community Energy Strategy", recently recognised by the US-based National Association of Counties as a national model. Arlington County is now following Loudoun's example with its own long-term comprehensive "Community Energy Plan". These efforts have reflected true community leadership, vision and hope when addressing lowcarbon technology development and deployment, meaningful climate change policies, and "green" jobs development.

This paper will look at Arlington County Virginia's efforts to become more economically competitive, energy efficient, sustainable and emit fewer greenhouse gases. It will review the county's experiences in the creation of green jobs to accelerate deployment of energy efficient and low-carbon technologies, practices and policies. This will be in the context of a plan to rapidly achieve global bestpractice energy performance. The paper also will look at the impacts on the overall attractiveness of the community as a place to live and work, including ways in which innovative energy systems create attractive investment opportunities for business. A major focus will be to review the importance of initiatives scaled to the community-level and the degree to which the examples are demonstrating the value of "scale" in implementation.

\section{Overview of Regional Energy, Climate and Economic Challenges}

Like most of the US, Virginia has not yet reached international benchmarks in terms of maximising energy efficiency, especially in the context of the built environment and associated transportation. Measured against global best practices, the region has challenges ahead in promoting and developing clean and renewable energy supply and in adopting more efficient transportation alternatives. A recent World Resources Institute study indicated that the cumulative greenhouse gas emissions of Virginia, South Carolina and North Carolina equal those of all of South Korea - currently the world's $18^{\text {th }}$ largest emitter. ${ }^{2}$ A study by the Washington Metropolitan Council of Governments revealed that Virginia generates approximately 20 tonnes per person of $\mathrm{CO}_{2} \mathrm{e} .{ }^{3}$ In addition, the American Council for an Energy Efficient Economy ranked Virginia 38th out of 50 states in overall energy efficiency programmes and technologies. ${ }^{4}$ The Brooking Institute quantified transportation and residential greenhouse gas emissions for the 100 largest US metropolitan regions. The Washington-Arlington-Alexandria region finished $100 .^{5}$ These 
results are largely caused by coal-based electricity, car-dependent transportation systems, combined with homes and buildings that are energy inefficient, even by US standards.

Pressures to develop sustainable energy systems increase as the numbers of people anticipated to move to the region rise. As just one example, the metropolitan Washington DC region must plan for over 1.5 million people between 2010 and 2040. This puts enormous demands on housing, transportation, and energy. In this region, the energy sector already accounts for over $66 \%$ of the region's greenhouse gas emissions. The Metropolitan Washington Council of Governments estimates energy consumption will rise by $33 \%$ by 2010 and $40 \%$ by 2050 , straining grids and networks. ${ }^{6}$ Energy prices have increased $14 \%$ for electricity, 53\% for natural gas, and 68\% for gasoline, between 2000 and 2005. The 2009 Loudoun Community Energy Strategy assessed that at approximately one-half of all energy used by the county was in the form of conversion and transmission losses in electricity generation. This study also indicated that the annual energy use per square meter of residential and commercial space in Loudoun County was about $500 \mathrm{kWh}$ (equivalent) per square meter. This is a level at least twice that of comparable European communities. ${ }^{7}$ Solely relying on the increase of renewable energy use to meet some of this demand is not a feasible option. A study by the Virginia Centre for Coal and Energy Research assessed that there is less than $300 \mathrm{~kW}$ of renewable electricity from solar photovoltaic and wind energy produced in all of Virginia. ${ }^{8}$

Many governments in the Northern Virginia region have declared goals to reduce greenhouse gas emissions for their entire communities. Some jurisdictions have signed the "Cool Counties" Initiative or the National Conference of Mayors "Climate Protection Agreement." Both of these programmes set aspirational reductions of greenhouse gasses by $80 \%$ by 2050 from levels between 1990 and 2005 . In reality, the actual scope of most of these initiatives is either confined to emissions from local government activities or to small demonstration projects at the scale of individual buildings, homes or a few handfuls of vehicles. Energy use by local governments is often less than $5 \%$ of the community total, underlying the challenges of scale. Meeting these community goals is made more challenging since US federal policy does not integrate transportation and urban planning, lacks the power to promote consistent and comprehensive energy efficiency standards for homes and buildings, and has limited influence over renewable energy targets and electricity grid design.

Focusing on economic and environmental energy sustainability at the level of voluntary actions around individual buildings will not meet Northern Virginia's future energy demands. For example, in the entire US, there are currently 20000 registered buildings under the US Green Buildings Council's LEED rating system. However, the rate of certifying new buildings and retrofitting existing buildings would have to increase logarithmically to cover a significant portion of approximately 129 million homes and 10 million commercial buildings in the US within a reasonable period of time. There is strong evidence that simply relying on voluntary rating systems such as LEED to create sustained high levels of energy efficiency may not be effective, particularly in the case of Northern Virginia. It is clear that scale is the key factor of implementation. Similarly, recommending predominantly voluntary measures must be examined more closely for effectiveness. 


\section{Governmental Response - State of Virginia}

The Commonwealth of Virginia has developed a range of responses to these energy-related challenges. In 2008, former Virginia Governor Kaine organised a "Commission on Climate Change" to assess greenhouse gas emissions sources and to establish an emissions reduction target. The Commission targeted 30\% emissions reduction below the business as usual projection by 2025 . At 161 million metric tonnes of carbon dioxide equivalent $\left(\mathrm{Mmt} \mathrm{CO}_{2} \mathrm{e}\right)$ this works out to be only slightly below the state's 2000 emission level of $163 \mathrm{MmtCO} 2 \mathrm{e}$. Virginia also announced a voluntary renewable (electricity) portfolio standard that targets investor-owned electric utilities to procure $15 \%$ of electricity by 2025 from renewable sources, from a baseline of $2007 .^{9}$

In 2010, the incoming Virginia Governor McDonnell produced the Virginia Energy Plan and declared that Virginia would be transformed into the "Energy Capital of the East Coast". The 2010 Energy Plan emphasises growth in traditional and alternative energy supplies, job development and investment as well as energy conservation and efficiency. Special emphasis was given to the investment of clean energy research and development through the work of the "Universities Clean Energy Development and Economic Stimulus Foundation." In addition, Governor McDonnell has pushed ahead a USD 500 tax credit for each green job created in the Commonwealth, and proposed legislation to reward investor-owned electric utilities for wind energy. ${ }^{10}$

However, in general, with the exception of the community energy planning work started in Northern Virginia, the rest of the Commonwealth is just beginning to develop energy implementation plans linking quantitative short and long-term goals, large-scale integration of land-use, transportation, energy efficient housing and buildings, cogeneration, renewable energy, and more efficient use of grids and networks. The underlying frameworks that ensure policies survive beyond electoral cycles will be the Commonwealth's greatest challenge. According to the US Energy Information Administration, annual per capita energy consumption in Virginia is 345 million BTU's compared to Germany's 176 million BTUs or France's 182 million BTUs and annual per capita energy consumption of the state is about $1.7 \%$ higher than the rest of the US. ${ }^{11}$

\section{Local Response - Arlington County}

At the local level, communities in Northern Virginia such as Arlington County, are developing and working to implement individual, community-wide comprehensive energy plans. These address energy security, energy supply and environmental challenges through recommendations that integrate energy efficiency, heat recovery, cleaner and renewable energies, flexible energy distribution, transit-oriented transportation, and quantitative benchmarks - what is increasingly referred to as Community Energy Planning (CEP). These CEPs are informed by forty years of pioneering and successful community energy management in many OECD member countries. Successful community energy plans on both continents incorporate the following attributes:

- world-class energy efficiency in homes, buildings and vehicles

- planning that integrates land-use and efficient transport choices

- district energy systems enabling efficient energy conversion and waste heat recovery

- multi-fuel flexibility including renewable energies 
- integrated (multi) utility approach both technically and institutionally

- large-scale development or redevelopment to gain early scale of new paradigms

- community engagement informed by quantitative benchmarks

- consistent implementation over decades supported by all political parties

Community energy planning also relies on increased energy efficiency code requirements, or their equivalent in market practices, for new and existing homes and buildings, reinforced with energy performance labelling programmes. Community energy plans support clean and renewable energy availability from biomass, solar, wind, and cogeneration. Community energy plans also support large-scale district energy systems along with integrated transportation and urban development planning.

These community energy plans do not necessarily emphasise the development and support of a few specific technologies or singular policies, but rely on a planned and integrated approach their energy and climate systems. They also often face the challenge that effective incentives or regulation, such as feed-in tariffs or building codes, are rarely within community jurisdiction, requiring either creativity at the local level, or compatible national policies.

The political and commercial leadership of Northern Virginia has taken notice of the success of community energy planning in OECD-member countries such as Germany and Denmark. For example it is often noted in the development of the Arlington Plan that between 1990 and 2007, Denmark and Germany have made energy efficiency gains that have outpaced economic growth. It also is noted that during the same period energy consumption per capita is no higher today than in 1990. In aggregate, these countries have cut total emissions by $10 \%$ below 1990 levels silencing the argument that thoughtful and integrated energy policies are invariably developed at the expense of economic development.

\section{Case Study: Arlington County, Virginia}

\section{Background}

Arlington is an urban county of approximately 26 square miles located directly across the Potomac River from Washington DC. The county's proximity to Washington DC, its public transportation network, and its highly skilled labour force have attracted an increasingly varied residential and commercial mix. ${ }^{12}$ The county's current estimated population is 212 300, and forecasted to grow to 247600 by 2040 . Arlington's economy revolves around the US Government and the related service industries consulting to the US Government.

In 2010, Arlington started to develop one of the nation's first long-term comprehensive Community Energy Plans. Benchmarked against global best practices, the plan has three overarching goals:

- enhance Arlington's economic competitiveness and provide high-quality jobs

- ensure reliable and affordable energy supplies

- demonstrate the county's long-term commitment to reducing its greenhouse gas emissions as outlined through signing the "Cool Counties" Initiative. 
All sectors of the community are actively engaged in the development of the plan - commercial, governmental, academic and non-governmental. Using energy-related greenhouse gas emissions per resident as a surrogate for energy productivity as a whole, a core sustainability goal of Arlington is to cut its per capita emissions to at least 3.0 tonnes $(\mathrm{mt})$ from the current 13.4 tonnes over the next 40 years. ${ }^{13}$ The county has committed a deeper goal of $2.2 \mathrm{mt} / \mathrm{capita}$ if surrounding jurisdictions share in credible, aligned community energy planning. The preliminary recommendations to meet the goal in ways that are economically viable and improve energy supply quality fall into four categories:

- Governance of the CEP implementation

- Specific targets and policies regarding built environment

- Specific targets and policies regarding transportation

- Cross-cutting initiatives

The governance recommendations include organisational aspects at the county and local neighbourhood level, and regular reporting of results including energy costs, investments and jobs created and environmental performance. In addition, the plan calls for, under cross-cutting initiatives, the creation of "high-quality green jobs" to implement the recommendations of the CEP.

The efficiency targets have been established for both existing and new construction and evolve over time. The effectiveness of these will be validated by a widening implementation of "Energy Performance Labelling" following a model similar that being adopted across the EU. Widespread adoption of efficient new construction and renovation will have a deep and transforming effect on the local employment in the buildings sector for a wide range of functions from investment, through construction and operational management.

The CEP includes an inventory of energy consumption, use and supply as well as greenhouse gas emissions. Of all the energy used county-wide, $53 \%$ was in non-residential buildings and a further $25 \%$ in homes. The transportation needs of residents consumed $9 \%$ and those of non-residents the remaining $12 \%$. With homes and buildings consuming 75\% of all energy, the efficiency and supply of the built environment are the major focus on the Arlington CEP. By energy type, the generation and use of electricity accounts for $64 \%$ of all the fuel consumed, followed by gasoline and diesel fuel at $21 \%$ and natural gas at $14 \%$.

The major impact of the use of electricity, mainly through losses in generation, transmission and distribution, strongly influences the Arlington CEP recommendations. Arlington has already recognised the challenge of transportation energy use, and through a decades-long multi-pronged approach including transit-oriented development, has achieved a lower portion of its total emissions than the US average. 
Figure 1: Arlington County 2007 Energy Overview

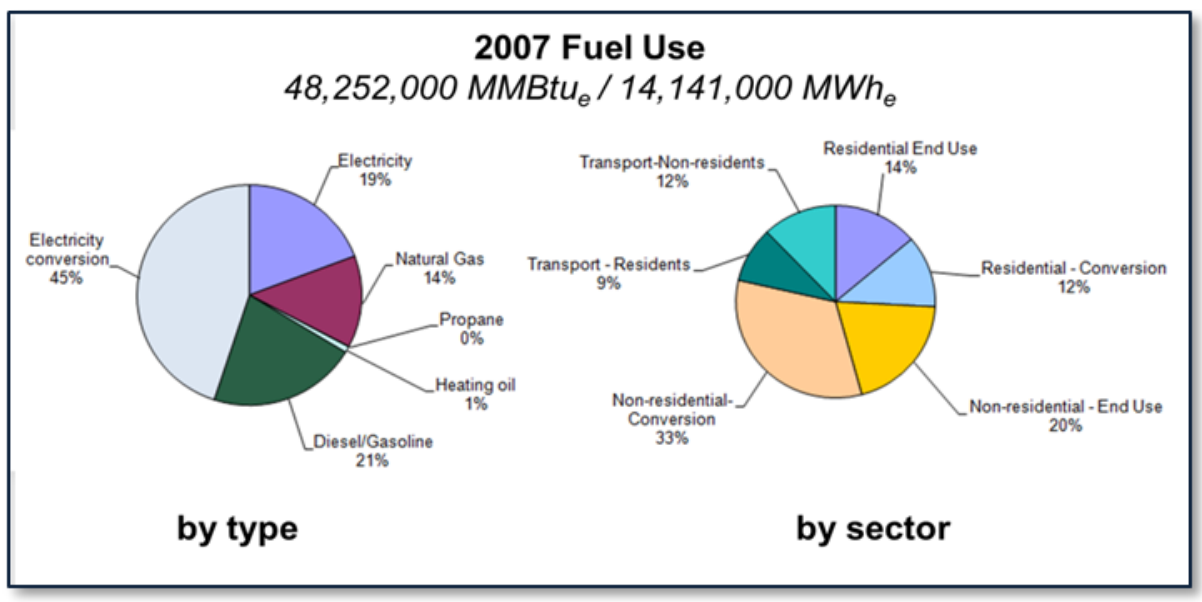

Arlington has the benefit of a long-term history with promoting density in urban planning and transitoriented development, especially along the Ballston-Rosslyn corridor and Crystal City. As a result, the Arlington CEP has assessed that district energy is could be a viable option in much of the county. It is proposed in the Arlington CEP that high-density areas such as Crystal City and the Ballston-Rosslyn Corridor have the potential to economically transition towards neighbourhood-scale district energy systems starting as early as 2015 .

Figure 2: Arlington County - Potential District Energy Zones

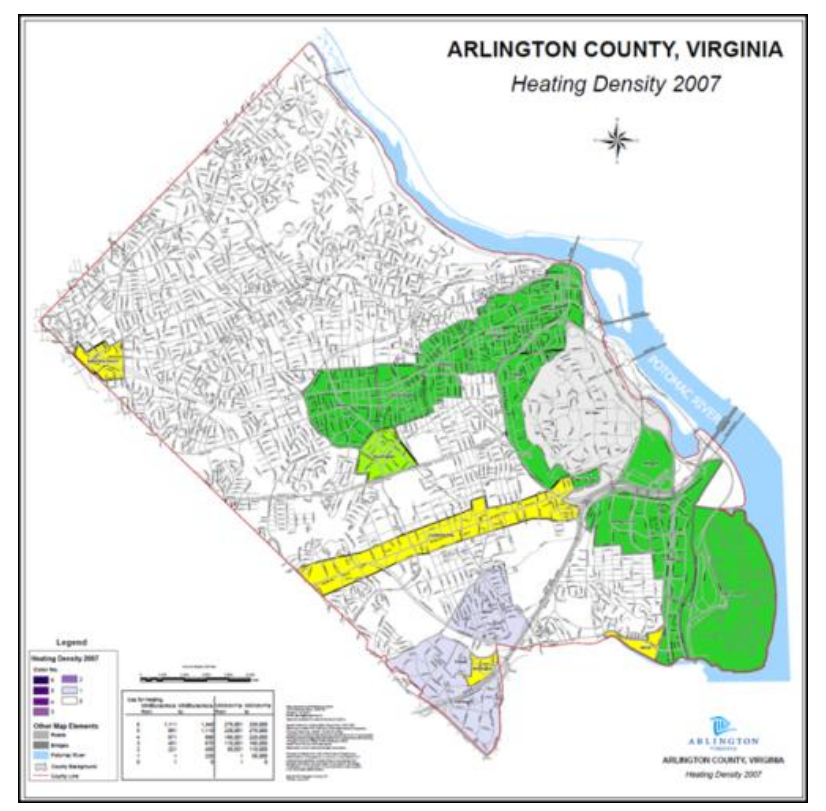

The CEP also calls for about $150 \mathrm{MW}$ of distributed cogeneration to both reduce the peak loads on the wider grid, to generate heat for the district energy system and to greatly reduce the GHG footprint. To both reduce the summer peak, and to further reduce GHG emissions, the plan recommends installing a total of $160 \mathrm{MW}$ of Solar PV capacity by about 2035. Like the widespread increases in efficiency, these strategies have the potential to promote transformational job growth in the district energy, and clean and renewable energy sectors. 


\section{Strategic Approach and Leadership}

A "Community Energy and Sustainability" (CES) Task Force was set up in early 2010 guide the development of the CEP. Its membership reflects the diversity of the Arlington community and includes officials from local, state and federal governmental, NGOs, academic, property development and management and other businesses, gas and electric utilities among others. The plan itself is developed by a team that includes both county staff and consultants with both US and European experience, ensuring there is good blend of local and global perspectives and benchmarking. The parallel public outreach and comment period for the CEP is extensive and accompanies the development of the plan from start to finish.

The preliminary recommendations of the task force were released in September of 2010, and will be refined ready for final approval in March 2011. Once the plan is completed, the recommendations also call for the introduction of new administration and governance processes designed to sustain the vision. Specifically, the plan recommends that the County Administration create a "County Energy Team," create and implement an "Energy Implementation Plan," and ensure that the CEP recommendations are reflected in the County General Plan and other county planning processes. ${ }^{14}$

\section{Pre-existing Programmes}

Arlington's CEP did not evolve in a vacuum. In 2007, the Arlington Initiative to Reduce Emissions (AIRE) was started to reduce emissions from local government operations by $10 \%$ from 2000 to $2012 .{ }^{15}$ The AIRE programme also includes help to recognise, assist and encourage businesses to reduce emissions and energy needs, to partner with federal Energy Star programmes, to encourage residents to reduce their energy usage, to reduce Arlington county's emissions from governmental operations via energy saving retrofits, and to increase recycling in county facilities, homes and businesses.

To support AIRE, Arlington County has developed the Arlington County Green Building Density Incentive Policy that incentivises high-density and mixed-use projects that conform to the US Green Building Council rating system. ${ }^{16}$ In addition to this, Arlington County was the first local government on the US East Coast to purchase energy-efficient hybrid-electric vehicles (Arlington's Green Fleet ${ }^{17}$ ). Fiftyseven percent of Arlington's fleet of 1148 vehicles are now cleaner, creating improved air quality, and reducing reliance on foreign sources of oil. Arlington County has also long-been recognised as a US national model for transit-oriented development and has won multiple national planning and transportation awards.

\section{Community Energy Plans and Impact on Employment}

Arlington County's CEP in its implementation, is designed to attract high-quality investment, job growth and environmental protection. It is important to emphasise that the Arlington CEP is a 40-year plan that frames a variety of potential implantation efforts. The long-term and comprehensive nature of the Arlington CEP alone makes it nearly unique among US energy plans at the sub-national level. There are no immediate solutions to redefining the energy performance of a community where most infrastructure already exists, and Northern Virginia and Arlington County are no exception.

The CEP calls for incrementally maximising the efficiency, reliability and flexibility of multiple existing systems to achieve world-class results - a story seen in the model cities of the OECD such as Copenhagen or Freiburg. They do not bet on individual "quick fixes" such as wind or solar PV at the expense of widespread community education, building retrofits, efficient, new construction, district energy, good energy housekeeping and transparency. These efforts will not deliver results overnight and require as much focus on governance, policy and market structure changes is needed as on technology and education. 
The Arlington CEP also calls for the development and implementation of energy distribution and supply systems that are proven and widely deployed in many OECD member countries, but not commonly applied in the US. Successful implementation of the CEP will create the foundation for county-wide (and eventually regional-wide) energy systems that will be among the first in the US. Collectively, the CEP creates the foundation to position Arlington County as a more efficient and globally competitive jurisdiction within the broader global economy.

The CEP's effect on "green job" creation in Northern Virginia and Arlington County will come in multiple ways.

- Construction and retrofits of homes and buildings: There will be opportunities in the architectural, engineering design, construction and building management areas. Data collected from a survey by the "Green Jobs Alliance," suggests that each $1 \%$ market penetration of energy efficiency retrofits in housing alone, jurisdictions in Northern Virginia such as Arlington, stand to gain approximately 1150 jobs. $^{18}$ The local payroll created in Northern Virginia could be between USD 28000000 and USD 40000000 . When commercial buildings are factored in, Arlington could be adding 200 to 300 jobs per year.

- Financing and validation of efficient construction: The CEP is calling for validated energy performance throughout a building's lifetime. This creates a transparency that ultimately allows the market to value energy efficiency in terms of rental and property values. This in turn will create a whole new cadre of employment in the investment, legal and contractual and performance certification areas. It is hard to put firm numbers on these, but indications from elsewhere are that they will be significant.

- District energy and distributed generation: Arlington reflects the US in that it makes no use of the heat generated during the production of electricity. To overcome this obvious barrier to breakthrough reductions in greenhouse gas emission, Arlington is recommending the implementation of district heating and cooling in its higher density neighbourhoods, supported by significant amounts of Combined Heat and Power. This strategy was benchmarked against successful examples such as Copenhagen and Mannheim. In a related initiative, the CEP calls for about $160 \mathrm{MW}$ of Solar PV to reduce summer peaks and reduce GHGs. This will create a substantial number of completely new jobs. These will be in investment planning, land-use planning, legal and contractual management, marketing, engineering, construction and operation of both CHP supplies and DE networks and large scale Solar PV.

- Professional and vocational training: The Arlington CEP contains an "implementing strategy" that has inventoried local education resources, such as the existing universities, trade and community college systems that are capable of assisting with job training needs, particularly to help meet the potential necessary specialist skills and resources that the CEP will stimulate. These could include the development and application of renewable energies, building retrofits, district energy, and related urban infrastructure. The CEP calls for scale, but scale calls for readily available human resources in sufficient quantities. The CEP will stimulate a substantial number for workforce training and education opportunities.

- Policy transfer: The Arlington CEP used global best practices and policies as an input to its recommendations. This approach tends to work best when it stays clear of abstract processes and sticks to problem-focused and goal-oriented efforts. Benchmarks from elsewhere are only relevant after they are appropriately assessed and studied for local adaptation. This adaptation effort and expertise around policy, market acceptance, and even some technical adaptation will be a source of a reasonable number of high-quality jobs. The answers that will be developed 
across Northern Virginia region will be both relevant and adaptable to accelerate the development of the region as national example of energy sustainability.

- Investment and market development-related jobs: By adopting an aggressive CEP, Arlington, and more widely Northern Virginia, is creating a "Market of First Resort" for the immediate region of some tens of millions of people, and ultimately for the US and Canada as a whole. The region will become a natural magnet for world-class companies looking to establish a foothold on the wider US market as it transforms its energy productivity. The population of Arlington is about 225 000, less than $1 \%$ of the US and Canadian totals. It is in a climatic zone that reflects both substantial heating and cooling demands, and is located close to a major centre of world power, Washington DC. The CEP will provide the initial local critical mass to justify initial business development investments and to hone solutions and skills to the market. This will then become a springboard for wider "export" of energy solutions to North America, creating highquality managerial and technical employment in both Northern Virginia.

\section{Conclusions and Lessons Learned}

This paper has attempted to give a flavour of the varied and creative ways the Northern Virginia region in general and Arlington County in particular is addressing the inter-related challenges and opportunities arising from sustainable energy management and economic development. Looked at collectively, Northern Virginia has key assets for several world-class energy, climate and green job creation programmes. These initiatives, and others like them across the region, are characterised by a serious acknowledgement of a strategic energy and climate challenge by the local government, businesses, and other environmental and civic leadership. This paper also identified several national challenges that have stalled long-term comprehensive energy and climate planning in the region and needs to be constantly addressed.

One of the more common challenges in the past has been an over-reliance on small-scale activities focused on local government operations and assets. This has often been accompanied by inadequate attention to jurisdiction-wide energy strategies supported by quantitative goals and benchmarks to measure progress. Another is the common tendency to over-rely on technical "silver bullet" remedies, without addressing the need for the large scale enhancement and maximising of efficiencies of existing (and largescale) systems. Large-scale job creation and meaningful economic development cannot emanate from a narrow, singular focus.

Arlington County and Northern Virginia are beginning to address the two-pronged challenge of energy transformation on a scale that drives meaningful job growth in a labour market that today lacks the necessary human resources. 


\section{NOTES}

1. www.deq.state.va.us/export/sites/default/info/documents/climate/CCC_Final_Report-Final_12152008.pdf

2. www.deq.state.va.us/export/sites/default/info/documents/climate/CCC_Final_Report-Final_12152008.pdf

3. www.mwcog.org/uploads/pub-documents/zldXXg20081203113034.pdf

4. www.aceee.org/press/2008/09/virginia-can-reduce-electricity-needs-20-\%-through

5. www.brookings.edu/reports/2008/05_carbon_footprint_sarzynski.aspx

6. www.mwcog.org/uploads/pub-documents/zldXXg20081203113034.pdf

7. www.aicgs.org/documents/pubs/polrep43.pdf

8. www.aicgs.org/documents/pubs/polrep43.pdf

9. www.deq.state.va.us/export/sites/default/info/documents/climate/CCC_Final_Report Final_12152008.pdf

10. www.dmme.virginia.gov/DE/VAEnergyPlan/2010-VEP/VEP-2010.pdf

11. www.deq.state.va.us/export/sites/default/info/documents/climate/CCC_Final_Report-Final_12152008.pdf

12. www.arlingtonva.us/departments/cphd/planning/data_maps/cphdplanningdataandmapsprofile.aspx

13. www.arlingtonva.us/departments/DES-CEP/CommunityEnergyPlan/CommunityEnergyPlanMain.aspx

14. www.arlingtonva.us/departments/DES-CEP/CommunityEnergyPlan/CommunityEnergyPlanMain.aspx

15. www.arlingtonva.us/portals/topics/aire/Climate.aspx

16. www.usgbc.org/DisplayPage.aspx?CategoryID=19

17. www.arlingtonva.us/portals/topics/ClimateGovernment.aspx

18. www.greenjobsalliance.org 